WiesŁaw FrancisZeK Murawiec OFM

\title{
PROFESORA DR. HAB. JANA SLAWOMIRA SAMKA ŻYCIE I TWÓRCZOŚĆ NAUKOWA W ZARYSIE
}

\section{MLODOŚĆ I PIERWSZE PRZYGODY Z NAUKA}

Profesor Jan Sławomir Samek jest obywatelem miasta Krakowa i całą swoja karierę naukową związał z podwawelskim Grodem. Urodził się w dniu 9 sierpnia 1930 roku przy ulicy Krowoderskiej, w rodzinie inteligenckiej, zadomowionej od trzech pokoleń w Krakowie ${ }^{1}$. Jego dziadek Szymon Samek przybył tu z Podkarpacia przy końcu XIX wieku i podjął pracę w Muzeum Książąt Czartoryskich przy ulicy Pijarskiej. Ojciec Jubilata Józef studiował prawo na Uniwersytecie Jagiellońskim i uzyskał doktorat nauk prawnych, a następnie pracował $\mathrm{w}$ Banku Rolnym w Krakowie jako jego wicedyrektor. Matka Maria z domu Stylińska wywodziła się z Kresów wschodnich i do swoich antenatów zaliczała m.in. arcybiskupa ormiańskiego Izaaka Mikołaja Isakowicza (zm. 1901). Była pierwszą kobietą zaangażowaną do pracy na Poczcie w Krakowie.

Po ukończeniu szkoły podstawowej J. S. Samek uczył się w Gimnazjum im. Jana III Sobieskiego w Krakowie, które ukończył z wyróżnieniem, uzyskując dyplom maturalny w 1950 roku. Swoje zainteresowania historią sztuki ujawnił już w latach gimnazjalnych, publikujac pierwsze artykuły o zabytkach, w czasopiśmie szkolnym „Orli Lot”. Były to przeważnie relacje z wycieczek krajoznawczych do różnych miejscowości, np. do Giebułtowa, Zielonek, Garlicy Murowanej $\mathrm{i}$ innych ${ }^{2}$.

${ }^{1}$ Ród Samków wywodzi się z Zakopanego, gdzie do dziś, pomiędzy Starym Kamieńcem a Chycowym Potokiem, w pobliżu dworca kolejowego ciągnie się uliczka „Do Samków”. W. Szczebak, Działalność naukowa $i$ wychowawcza Profesora Jana Samka. W: Sztuka i Pedagogika. T. 2. Kraków 1999, s. 16.

${ }^{2}$ Należa tu artykuły z roku 1949 i 1950: Wycieczka krajoznawcza do Giebuttowa, Zielonek, Garlicy Murowanej (Orli Lot 1949 nr 3, s. 40-42, rys. 1 - 2), Jurajskim szlakiem „Orlich Gniazd” (Orli Lot 1949 nr 4, s. 124-126, rys. 1-6), Obozy i wycieczki. Szlakiem „Orlich Gniazd”. Wyjatek z kroniki Obozu Wędrownego (Orli Lot 1949 nr 10, s. 157-160, fot. 1-3), Obozy i wycieczki. Szlakiem "Orlich Gniazd". Dziennik Kota Krajoznawczego uczniów Szkoty Ogólnokształcacej Stopnia Licealnego im. Króla Jana III Sobieskiego w Krakowie (Orli Lot $1950 \mathrm{nr}$ 1, s. 11-26, fot. 1-4, plany 1-3, rys. 1-2), Szlakiem Orlich Gniazd (c.d.) /Orli Lot $1950 \mathrm{nr}$ 2-3, s. 35-59, fot. 1-7, plany 1-7, rys. 1-7/, Szlakiem Orlich Gniazd (c.d.) /Orli Lot $1950 \mathrm{nr} 4-5$, s.71-93, fot. 1-5, plany 1-6, rys. 1-7/, Szlakiem Orlich Gniazd (c. d.) /Orli Lot 1950 nr 6-7, s. 102-116, fot. 1-4, plany 1-6, rys. 1-7/. 
Studia wyższe na Uniwersytecie Jagiellońskim w Instytucie Zabytków Sztuki rozpoczął w 1951 roku i jako student należał do Koła Naukowego, którego był prezesem i przewodniczącym Sekcji Inwentaryzacji Zabytków. Już od początku studiów pracował w ramach inwentaryzacji zabytków miasta Krakowa, zainicjowanej przez prof. Adama Bochnaka dla potrzeb „Katalogu Zabytków Sztuki w Polsce". Dzięki temu student J. S. Samek rozpoczął w pierwszych latach 50-tych prace inwentaryzacyjne w kościołach i klasztorach Krakowa. Na drugim roku studiów doszła jeszcze, trwająca cztery lata praca w Urzędzie Wojewódzkiego Konserwatora Zabytków w Krakowie, która polegała na sporządzaniu dokumentacji naukowej i pracach archiwalnych. Wszystko to stwarzało młodemu studentowi duże możliwości poznania i umiłowania wielu zabytków sztuki sakralnej. Już podczas studiów nawiązał kontakt z Instytutem Sztuki Polskiej Akademii Nauk w Warszawie, dla którego przeprowadził inwentaryzację zabytków na terenie powiatów północnej Polski, szczególnie Działdowa, Moraga i wielu innych $^{3}$.

Studia uwieńczył dyplomem magisterskim w 1955 roku na podstawie pracy pt. „Rozwój chrzcielnic w Polsce”, napisanej pod kierunkiem prof. A. Bochnaka Już w roku uzyskania magisterium J. S. Samek zorganizował wraz z innymi absolwentami historii sztuki Zespół Naukowy, stawiajacy sobie za cel tworzenie dokumentacji historycznych zabytków sztuki do prac konserwatorskich. Pochlebna opinia prof. Bochnaka świadczy, że miał „uzdolnienia i zamiłowanie do zespołowej pracy naukowej (...) w zakresie kultury artystycznej". Karierę naukową na Uniwersytecie Jagiellońskim J. S. Samek rozpoczałł w 1956 roku uzyskując asystenture w Instytucie Historii Sztuki w ramach Katedry Historii Sztuki Nowożytnej.

W 1956 roku J. S. Samek zawarł związek małżeński z Izabellą Rejduch, z litewskiej rodziny Brzytwa-Dobrzyńskich. Sakramentu małżeństwa udzielił im duszpasterz akademicki ks. Jan Pietraszko ${ }^{5}$, późniejszy biskup pomocniczy krakowski. Uroczysta ceremonia miała miejsce w akademickim kościele Św. Anny w Kra-

${ }^{3}$ Sa to pozycje nie opublikowane (w posiadaniu autora): Powiat działdowski. Katalog Zabytków Sztuki w Polsce. /Dawne/ województwo olsztyńskie (Wspólnie z T. Chrzanowskim i M. Korneckim). - Praca złożona do druku w Instytucie Sztuki PAN w Warszawie; Powiat moragski. Katalog Zabytków Sztuki w Polsce. /Dawne/ województwo olsztyńskie (Wspólnie z T. Chrzanowskim i M. Korneckim). - Praca złożona do druku w Instytucie Sztuki PAN w Warszawie.

${ }^{4}$ Promotor Jubilata prof. UJ Adam Bochnak (1899 - 1974) kjerował Zakładem Historii Sztuki (później Katedrą Historii Sztuki Nowożytnej). Był też wicedyrektorem Państwowych Zbiorów Sztuki na Wawelu, dyrektorem Muzeum Narodowego w Krakowie, członkiem Komisji do spraw Sztuki Kościelnej Archidiecezji Krakowskiej. - J. Samek, Bochnak Adam. W: Encyklopedia Katolicka. T. 2. Pod red. R. Lukaszyka i Z. Sułowskiego. Lublin 1977, kol. 696; J. Kuś, Jubileusz Profesora Adama Bochnaka. „Nasza Przeszłość” 38: 1972, s. 285; T. Chrzanowski, Profesor. „Tygodnik Powszechny" 28: $1974 \mathrm{nr} 24$.

${ }^{5}$ Shuga Boży bp Jan Pietraszko (1911-1988) był od roku 1948 duszpasterzem akademickim przy kościele Św. Anny w Krakowie, a w latach 1957-1958 pełnił funkcje proboszcza tegoż kościoła. Konsekrację biskupią otrzymał w katedrze na Wawelu w 1963 roku. Zmarł drugiego marca 1988 roku. W sześć lat po śmierci rozpoczęto jego proces beatyfikacyjny, dlatego przysługuje mu tytuł "Sługa Boży”. - G. Ryś, Pietraszko Jan, kryptonim: $x$. W: Stownik polskich teologów katolickich. T. 8. Pod red. ks. J. Mandziuka. W. 1995, s. 462; W. Gasidło, Ze wspomnień o ś. p. księdzu Biskupie Janie Pietraszce. „Notificationes e Curia Cracoviensi”. R. 126: 1988 nr 3-4, s. 59. 
kowie $^{6} \mathrm{w}$ dniu 21 kwietnia tegoż roku. Izabella Samkowa, żona Jubilata była również historykiem sztuki znanym w literaturze jako autorka cennych opracowań o judaikach w Polsce. Miała swój poważny udział w wielu późniejszych przedsięwzięciach naukowych i organizacyjnych męża, $\mathrm{m}$. in. w opracowywaniu tomów „Katalogu Zabytków Sztuki w Polsce” dla różnych regionów naszego kraju.

Ważnym okresem w życiu rodzinnym Państwa Samków było przyjście na świat syna, Mariusza Tomasza, w 1957 roku, a w dwa lata później - córki Elżbiety. Okres dzieciństwa i młodości przypadający na ostatnie lata 50-te do 70-tych włącznie, był wypełniony troską Rodziców o ich wychowanie i wykształcenie ${ }^{7}$.

Współpraca naszego Jubilata $\mathrm{z}$ prof. Adamem Bochnakiem rozpoczęta w czasie studiów uniwersyteckich (1951-1955) trwała nadal, szczególnie w pracach nad serią tomów „Katalogu Zabytków Sztuki w Polsce”, „, W nich bowiem zaczęła się działalność naukowa Jana Samka - stwierdza prof. Bochnak - one również stanowią jakby rdzeń tej działalności (...) z naciskiem należy podkreślić, że ta akcja wydobyła na jaw długi szereg dzieł sztuki dotychczas nieznanych, a mających nieraz znaczną wartość artystyczną i doniosłe znaczenie w rozwoju naszej sztuki" ". W niezwykle cennych „Katalogach Zabytków Sztuki Województwa Katowickiego" (14 tomów) i miasta Krakowa (Cz. 2, 3 i 4, 5, 6, 8) zaprezentował nasz autor ściśle naukową akrybię i benedyktyńską wprost dokładność opisów.

Doktorat nauk humanistycznych w zakresie sztuki uzyskał J. S. Samek w 1962 roku na podstawie rozprawy pt. „Nawrót do gotyku w sztuce Krakowa w pierwszej połowie XVII wieku"10, pod kierunkiem profesora A. Bochnaka ${ }^{I 1}$. Praca w dużej mierze dotyczyła przemian zachodzacych w sztuce kościelnej i klasztornej Krakowa. Już przed uzyskaniem stopnia doktora J. S. Samek nawiązał wieloletnią współprace z Polskim Słownikiem Biograficznym, dla którego opracowywał artykuły bio-bibliograficzne wielu malarzy, architektów, złotników, rzeźbiarzy $\mathrm{i}$ innych artystów.

Do roku 1973 nasz Jubilat pracował na Uniwersytecie Jagiellońskim jako adiunkt, a następnie otrzymał od władz uniwersytetu urlop w celu zorganizowa-

${ }^{6}$ Opracowanic pt. Uniwersytecka kolegiata św. Anny w Krakowie, autorstwa naszego Jubilata, liczaca 112 stron i 87 ilustracji, ukazało się w Krakowie w roku 2000. - Por. Bibliografia Profesora dr, hab. Jana Stawomira Samka nr 430.

${ }^{7}$ Mariusz Tomasz Samek historyk sztuki i artysta fotografik pracuje obecnie w Stadt Museum w Münster, a jego siostra Elżbieta działa w kraju jako architekt i scenograf. Urozmaica niektóre publikacje swoich rodziców pięknymi rysunkami obiektów zabytkowych. - Por. J. Konieczna, Curriculum vitae /Jana Stawomira Samka/. W: Sztuka i Pedagogika I. Pod red. J. S. Samka. Kraków 1997, s. 155; W. Szczebak, Dziatalność naukowa $i$ wychowawcza ... W: Sztuka i Pedagogika II. Kraków 1999, s. 18; J. S. Samek, Przewodnik po mieście Alwerni i okolicy. Kalwaria Zebrzydowska 1995 (Przedmowa W. F. Murawca OFM).

${ }^{8}$ Por. m. in. Bibliografia Profesora dr. hab. Jana Stawomira Samka, nr 53-55, 120-122.

${ }^{9}$ Archiwum UJ Rkp. A. Bochnak, Opinie /o pracach dyplomowych/.

${ }^{10}$ Streszczenic pracy ukazało się w Sprawozdaniach z posiedzeń Komisji Oddziału PAN w Krakowie, w 1966 r. (s. 548-550).

"Recenzentami pracy doktorskiej J. S. Samka byli profesorowie: Józef Edward Dutkiewicz i Lech Kalinowski. Sama zaś obrona miała miejsce na Uniwersytecie Jagiellońskim, na ówczesnym Wydziale Filozoficzno-Historycznym w Instytucie Historii Sztuki. 
nia Pracowni Inwentaryzacji Zabytków Miasta Krakowa PAN. Zorganizował wówczas zespół pracowników inwentaryzacji, pracujący z wielkim zapałem i oddaniem dla sprawy, którym kierował do czasu stanu wojennego, do roku 1983. Zarówno kierujący pracami Profesor jak i członkowie zespołu mieli ambicje utworzenia w Krakowie największego w Polsce ośrodka inwentaryzacji zabytków sztuki. Znawcy bardzo wysoko oceniaja prace zespołu Profesora J. S. Samka, szczególnie na terenie kościołów i klasztorów Krakowa ${ }^{12}$. Ukierunkowanie na sztukę i architekturę kościelną stanowiło w tym czasie kontynuację zamierzeń i jakby wypełnienie testamentu poprzedników Jubilata w dziedzinie sztuki w Krakowie, a zwłaszcza profesorów: Mariana Sokołowskiego ${ }^{13}$, Juliana Pagaczewskiego $^{14}$ i Adama Bochnaka.

\section{DALSZE SUKCESY NAUKOWE I WYCHOWANIE PRZEZ SZTUKE}

W latach 1967-1991 oraz w latach 90-tych J. S. Samek poświecił swoje badania naukowe przede wszystkim zagadnieniom związanym ze sztuką ściśle polską oraz pochodzącą „z importu”, ukierunkowaną na zdobnictwo średniowieczne i nowożytne. Na pierwszy plan w swoich zainteresowaniach naukowych wysuną rzemiosło artystyczne, omawiając dzieła zarówno polskich, jak i obcych artystów działających w Polsce. Należy tu wymienić $m$. in. monumentalne publikacje albumowe z lat 70-tych i 80-tych pt. "Res - imagines (...), 1600-1800", „Skarby Jasnej Góry" (wydawane 19 razy, w pięciu różnych wersjach językowych), „Polskie rzemiosło artystyczne. Czasy nowożytne” i „Dzieje złotnictwa w Polsce” (Warszawa 1993, s. 1-70, il. 1-204) ${ }^{15}$. Sa to dzieła liczące od kilkudziesięciu do 465 stron, w których tekst zajmuje na ogół większą część, względnie $50 \%$ całości opracowania $^{16}$. W pracach tego okresu ważne miejsce zajmują także mniejsze

${ }^{12}$ Pracownia Inwentaryzacji Zabytków mieściła się w domu zabytkowym przy ul. Floriańskiej 21 na pierwszym i drugim piętrze.

${ }_{13}$ Marian Sokolowski (zm. 1911) byl historykiem sztuki, profesorem UJ od roku 1882 i członkiem PAU, współzałożycielem Domu Jana Matejki, długoletnim dyrektorem Muzeum Czartoryskich i przewodniczącym Grona Konserwatorów. - Por. A. Ś r ó d k a, Uczeni polscy XLX $i$ XX stulecia, T. 4. Warszawa 1998, s. 146-147; S. T u r c z y ń s k i, Marian Sokołowski, 1839-1911. Kraków 1911, s. 30 n.

${ }_{14}$ Julian Pagaczewski (zm. 1940) był historykiem sztuki, profesorem UJ. Z pasją zajmował się badaniem rzemiosła artystycznego. Wspólnie z A. Bochnakiem opracowal m. in. książkę Zabytki rzemiosta artystycznego $w$ kościele parafialnym w Luborzycy (Kraków 1925). Jako profesor UJ i dyrektor Komisji Historii Sztuki PAU w swojej pracy pedagogicznej kładł nacisk na seminaria i ćwiczenia w terenie, przeważnic w kościołach, klasztorach i prywatnych zbiorach. Jego uczniami byli m.in. Adam Bochnak i Jerzy Szablowski. - A. B o c h n a k, Pagaczewski Julian (1874-1940). W: PSB, t. 25, s. 16, 18; tenże, Historia sztuki w Uniwersytecie Jagiellonskim. W: Studia z dziejów Wydziału Filozoficzno-Historycznego UJ. Zeszyty Naukowe UJ 139, Prace Hist. nr 16 Kraków 1967, s. 234; A. B o c h n a k, K. P i e r a d z k a, Czterdziestolecie Towarzystwa Mitośników Historii i Zabytków Sztuki Krakowa. Kraków 1937.

${ }^{15}$ Bibliografia J. S. Samka..., nr 326.

${ }^{16}$ W. F. M u raw i e c OFM, $O$ działalności naukowej $i$ dydaktycznej prof. dr hab. Jana Samka w zarysie. (Kraków 1999), s.2 /Ms. bez sygn. w posiadaniu APBK w Krakowie/. 
objętościowo, ale źródłowo udokumentowane artykuły o rzemiośle artystycznym, jako dziełach twórców krajowych i obcych, działających w Polsce. Dzięki tej twórczości J. S. Samka mamy wydobyte ze źródeł dane o pracach m. in. Leopolda Lenharda (vel Lenkarta) z Wiednia i Jana Szilassy'ego z Lewoczy ${ }^{17}$, a także o dziełach złotniczych i jubilerskich innych twórców działających w Polsce ${ }^{18}$. Ponadto tematyczne ujęcia biblijnego "Drzewa Jessego" oraz judaika w sztuce staropolskiej ${ }^{19}$. W końcu także prezentacja anonimowych przedmiotów sztuki sakralnej późnego średniowiecza, jak na przykład „bacula pastoralia” w kościele Mariackim w Krakowie ${ }^{20}$.

Poza wymienionymi opracowaniami o charakterze albumowym oraz „Katalogami Zabytków Sztuki", mocno osadzonymi w literaturze źródłowej mamy w tym okresie cały szereg prac Jubilata z zakresu ikonografii, stanowiącej oryginalne dzieła rodzimych mistrzów pędzla, jak i naśladownictwa malarzy obcych, a w tym P. P. Rubensa ${ }^{21}$. Praca naukowa J. S. Samka w latach 90-tych stanowi kontynuację problematyki twórczej z lat wcześniejszych, a więc dotyczącej twórców polskich i obcych na terenie Polski. W ostatnich latach kończącego się wieku XX wiele zainteresowania wykazał także w takich tematach naukowych jak: „Wychowanie przez dawną i nowa sztukę" oraz „Funkcje edukacyjne zabytków w terenie i w skarbcach". Wiele wysiłku badawczego poświęca do dnia dzisiejszego ukazywaniu walorów rzemiosła artystycznego. Jest to szczególnie widoczne poza wyżej wymienionymi, w pracach: „Zapomniane wyroby ludwisarstwa nyskiego w Krakowie” (1994) ${ }^{22}$ oraz w książce pt. „Polskie rzemiosło artystyczne. Średniowiecze" (s. 1-343, il. wielobarwnych 16 , czarno białych 218$)^{23}$. $\mathrm{W}$ ostatnich latach na poczet kontynuacji wcześniejszej problematyki twórczej należy zapisać niezwykle wnikliwą i czasochłonną inwentaryzację krakowskich dzieł sztuki w „Katalogu Zabytków Sztuki w Polsce (IV). Kazimierz-Stradom. Kościoły i klasztory (1). Miasto Kraków (cz. IV)” oraz: „Kościoły i klasztory (2). Miasto Kraków (cz. V) ${ }^{\text {,24 }}$. Należy tu także inwentaryzacja krakowskich judaików Kazimierza i Stradomia (cz. IV). Obie części Katalogu zabytków w Krakowie J. S. Samek wykonał jako współautor, wraz ze swoją małżonką Izabellą RejduchSamkową. Zresztą opracowaniu judaików poświęcił Profesor wiele wcześniejszych prac od pierwszych lat 80 -tych ${ }^{25}$, z których książka pt. „Dzieje sztuki ży-

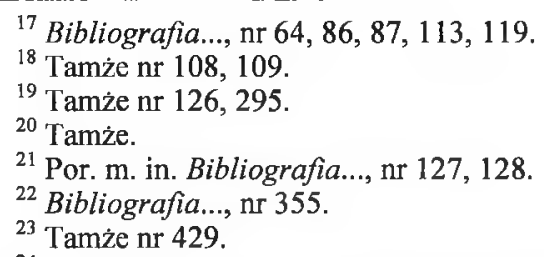

${ }^{24}$ Kontynuację Katalogu krakowskich zabytków stanowią nieopublikowane opracowania pt. Garbary. Kościoly i klasztory (1); Garbary. Kościoły i klasztory (2); Powiat moragski (dawne) województwo olsztyńskie (wspólnie z T. Chrzanowskim i M. Korneckim); Powiat przemyski (dawne) województwo rzeszowskie (wspólnie z T. Chrzanowskim i M. Korneckim); Powiat hrubieszowski, województwo lubelskie (wspólnie z T. Chrzanowskim i M. Korneckim). - Por. Bibliografia..., $\mathrm{nr} 26$.

${ }^{25}$ Bibliografia..., nr 158, 256, 285, 298-299, 360-362, 365-366, 377, 402, 413. 
dowskiej w Polsce" (współautorstwo z I. Rejduch-Samkowa) czeka na opublikowanie $^{26}$. Opracowanie krakowskich judaików kontynuował w latach 90-tych i opublikował pt. „Judaika w zbiorach Muzeum Uniwersytetu Jagiellońskiego I. Wyroby z kamienia i metalu"27.

Od lat 80. Profesor J. S. Samek rozpoczął ścisłą współpracę z Instytutem Pedagogiki na Uniwersytecie Jagiellońskim. W latach 1987-1992 zorganizował sześć obozów naukowych połączonych $\mathrm{z}$ wykładami $\mathrm{w}$ terenie, w kościołach, klasztorach i muzeach, dla studentów-seminarzystów ze specjalności pedagogiki kulturalno-oświatowej. W rezultacie stosowania metody prowadzenia seminariów, polegającej na bliższym kontakcie pracowników naukowych ze studentami, w otoczeniu sakralnych zabytków i eksponatów muzealnych - obok waloru wychowawczego - metoda ta posiadała także aspekt ściśle naukowy przejawiający się w zainteresowaniach studentów i stosunkowo licznych pracach magisterskich z pogranicza pedagogiki i historii sztuki. Promotorem inspirującym do takich studiów był zawsze nasz Jubilat, który w kwietniu 1993 roku wysunął projekt utworzenia Zespołu do Badań nad Edukacją Kulturalną. Członkami Zespołu stali się pracownicy Instytutu Pedagogiki, doktoranci i inni współpracownicy. Celem ich działalności pod kierunkiem Profesora stało się badanie oraz prognostyka wszelkich objawów i możliwości edukacji kulturalnej oraz ich inspirowanie i stwarzanie warunków rozwoju. Na terenie Instytutu Pedagogiki UJ Zespół przeprowadził w latach 1994-1995 dwie sesje naukowe w terenie, poświęcone problematyce dzieł sztuki w dydaktyce terenowej oraz zagadnieniom zwiazanym ze sztuką na terenie rodziny oraz problematyce rodziny w sztuce.

W rezultacie ożywionej działalności Zespołu do Badań nad Edukacją Kulturalną władze uczelni, dzięki staraniom Profesora J. S. Samka powołały do życia w ramach Instytutu Pedagogiki, w roku 1996, Zakład Wychowania przez Sztu$\mathrm{ke}^{28}$, którego kierownikiem został oczywiście nasz Jubilat. O żywotności zakładu świadczą m. in. dwie sesje naukowe urządzone w latach 1997 i 1999. Pierwsza o charakterze ogólnopolskim pod hasłem: „Wychowanie przez sztukę”, połączona z 40-leciem pracy naukowej Profesora J. S. Samka oraz druga także ogólnopolska, na temat: „Edukacyjne aspekty wielowyznaniowej sztuki w Polsce,29.

Pasja bezpośredniego kontaktu z dziełami sztuki w trakcie przekazywania o nich wiedzy, oraz czerpania $\mathrm{z}$ tego kontaktu doznań estetycznych były powodem gromadzenia się przez wiele lat wokół Profesora pracowników naukowych, doktorantów i studentów, których pociagała zawsze tematyka sztuki i jej oddziaływania na ducha ludzkiego. Profesor Jan Samek może się poszczycić ogromnymi sukcesami w tym zakresie. Przeprowadził 263 magisteriów (w tym około 50

${ }^{26}$ Tekst złożony w W. A. F.

${ }^{27}$ Por. Bibliografia..., nr 377.

${ }^{28}$ Zakład Wychowania przez Sztukę został oficjalnie powołany przez Radę Naukową Instytutu Pedagogiki oraz Radę Naukową Wydziału Filozoficzno-Historycznego UJ. Ostateczne zatwierdzenie decyzji o jego utworzeniu wyraził Senat Uczelni i jej Rektor. Wielka w tym również zasługa dyrektora Instytutu, prof. Stanisława Palki, który w latach wcześniejszych otaczał zespół życzliwą opieką. - Z relacji ustnych kierownictwa i członków Zakładu.

${ }^{29}$ Bibliografia..., nr 411, 417, 418, 419, 423. 
na Papieskiej Akademii Teologicznej), sześć doktoratów na UJ, PAT i PAN, a kolejne cztery prace są gotowe lub na ukończeniu. W bieżącym roku akademickim 2000/2001 jest otwartych 16 przewodów doktorskich na wymienionych uczelniach, pod kierunkiem naszego Profesora ${ }^{30}$.

Do innych prac Jubilata związanych z organizowaniem działalności naukowej na terenie Krakowa należy zaliczyć sesje naukowe organizowane w ramach stałej współpracy z Muzeum Historycznym Miasta Krakowa, gdzie Profesor kieruje wieloosobowa Radą Naukowa. W wyniku tej współpracy doszło do organizowania w Krzysztoforach serii wystaw zabytków sztuki klasztorów krakowskich: oo. Bernardynów (1997) ${ }^{31}$, sióstr Bernardynek (1998), oo. Franciszkanów - Reformatów (1998), sióstr Prezentek (1999) i oo. Franciszkanów (2000). Przewodniczący Zakładu Wychowania przez Sztukę Profesor J. S. Samek zorganizował ponadto cztery sesje naukowe związane tematycznie $\mathrm{z}$ prezentowanymi podczas trwania wystaw, zabytkami klasztornymi. Referentami byli przeważnie pracownicy naukowi UJ, PAT i PAN w Krakowie.

Niemal od początku swojej działalności w zakresie historii sztuki Jubilat zajmował się zabytkami klasztornymi i w ogóle kościelnymi. Można tu wskazać na pozycje zamieszczone w jego „Bibliografii”, umieszczonej na początku tego tomu $^{32}$. Stosunkowo najwięcej prac w swojej twórczości o zakonach Profesor poświęcił klasztorowi oo. Paulinów na Jasnej Górze (w tym najwięcej o Cudownym Obrazie Matki Bożej Częstochowskiej) ${ }^{33}$ oraz klasztorom oo. Bernardynów w Polsce ${ }^{34}$. Ponadto po kilka pozycji o klasztorach oo. Dominikanów ${ }^{35}$, oo. Franciszkanów Konwentualnych ${ }^{36}$, oo. Kapucynów ${ }^{37}$, sióstr Klarysek św. Andrzeja w Krakowie ${ }^{38}$, oo. Franciszkanów Reformatów ${ }^{39}$, Karmelitów na Piasku ${ }^{40}$, księży Kanoników Regularnych Laterańskich (Bożego Ciała $w$ Krakowie) ${ }^{41}$ i oo. Cystersów w Mogile ${ }^{42}$.

Wieloaspektowość badań w Zakładzie kierowanym przez Profesora sprawiła, iż w roku 2000/2001 władze Uniwersytetu Jagiellońskiego przemianowały Zakład Wychowania przez Sztukę na Zakład Pedagogiki Kultury.

${ }^{30} \mathrm{Z}$ relacji ustnej Prof. J. S. Samka z 25.10.2000 r.

${ }^{31}$ Organizatorem wystawy ze strony Muzeum Historycznego Miasta Krakowa był p. Janusz Nowak; ze strony klasztoru oo. Bernardynów w Krakowie - o. Wiesław Murawiec. Wystawę zabytków ss. Bernardynek przygotowywała $\mathrm{m}$. in. s. Benigna Dziwota.

${ }^{32}$ Ogólnie zakonów, względnie klasztorów krakowskich w Bibliografii dotyczą pozycje: nr $14,60,116,154,283,291,312,318,322,374$.

${ }^{33}$ Por. Bibliografia J. S. Samka, nr 94-95, 145, 152-153, 160-161, 171-173, 176, 218, 233, $235,247,251,395,397$.

${ }^{34}$ Bibliografia ..., nr 76, 240-242, 324, 330, 337, 342, 349-353, 357, 363-364, 369, 370, $376,400,409$.

${ }^{35}$ Bibliografia..., nr 78, 164, 194-195, 224.

${ }^{36}$ Tamże nr 65, 378, 390.

${ }^{37}$ Tamże nr 394, 415.

${ }^{38}$ Tamże nr 177, 398 .

${ }^{39}$ Tamże nr 334.

40 Tamże nr 393.

41 Tamże nr 117.

${ }^{42}$ Tamże nr 311. 
W latach 80-tych Profesor Jan Samek nawiązał współpracę z Papieską Akademią Teologiczną w Krakowie, przyjmując w 1987 roku propozycję dziekana Wydziału Historii Kościoła PAT ś. p. Profesor Janiny Bieniarzówny, prowadzenia wykładów i seminariów w zakresie historii sztuki. W dwa lata później przyjął nominację na kierownika Katedry Historii Sztuki w Polsce. Z jego inicjatywy na Wydziale Historii Kościoła PAT utworzono w 1991 roku kierunek Historii Sztuki Sakralnej. Profesor został opiekunem specjalizacji Historii Kultury i Sztuki Sakralnej, obejmujący część Katedry Kultury Religijnej. Wystąpił też z projektem utworzenia Instytutu Kultury Religijnej. Głównym celem projektowanego Instytutu miało być pogłębienie wśród duchowieństwa i świeckich wiedzy w zakresie kultury i sztuki religijnej. - Wykłady prowadzone przez Profesora na PAT dotyczą historii sztuki sakralnej w Polsce od roku 1000 do czasów najnowszych. Obejmują problematykę z zakresu architektury, malarstwa, rzeźby oraz rzemiosła artystycznego ukierunkowanego na sacrum. Wszystkie zajęcia prowadzone przez J. S. Samka odbywały i odbywają się nadal nie na jednym tylko miejscu, ale w terenie: w kościołach, kaplicach, klasztorach i muzeach. Cieszyły się dużą popularnością wśród studentów ceniących sobie oryginalną metodę prowadzenia zajęć $w$ otoczeniu zabytkowych pomieszczeń i przedmiotów. Niekiedy liczba słuchaczy Profesora dochodziła do 70 osób. - Jako Profesor PAT J. S. Samek zorganizował $\mathrm{m}$. in. sesję tzw. ,amerykańską", poruszającą tematykę kultury indiańskiej na drugiej półkuli, dostrzeżoną wśród zabytków sztuki sakralnej w Krakowie. Także sesję poświęconą pamięci ks. Piotra Skargi SJ, oraz jubileuszową z okazji 600-lecia osiedlenia oo. Karmelitów na Piasku w Krakowie i ostatnio - sesje poświęcona kultowi św. Wojciecha w Krakowie.

W latach 1995-1998 Profesor J. S. Samek kierował Studium Doktoranckim Wydziału Filozofii UJ, które cieszyło się dużym powodzeniem i należało do najlepiej zorganizowanych na Uniwersytecie. Ponadto od szeregu już lat prowadzi międzyuczelniane seminarium doktoranckie, na które uczęszczali doktoranci z Uniwersytetu Jagiellońskiego, Papieskiej Akademii Teologicznej, a także z muzeów Krakowa, Gdańska, Olkusza i Przemyśla.

\section{STOPNIE I WYRÓŻNIENIA WIEŃCZACE DOROBEK NAUKOWY.} PODSUMOWANIE

Już w roku 1974 praca J. S. Samka pt. „Koncepty w polskiej sztuce nowożytnej" stanowiła podstawę uzyskania stopnia doktora habilitowanego. W dwa lata później został powołany na stanowisko docenta w Instytucie Sztuki Polskiej Akademii Nauk w Krakowie. Bogaty i niezwykle cenny dorobek naukowy uwieńczony habilitacją otwierał przed docentem J. S. Samkiem szerokie możliwości prowadzenia wykładów, seminariów i obozów naukowych w różnych ośrodkach akademickich. A więc prowadził je nie tylko w Uniwersytecie Jagiellońskim i Polskiej Akademii Nauk w Krakowie, a później w Papieskiej Akademii Teologicznej, ale również w Katolickim Uniwersytecie Lubelskim, w Uniwersytecie Warszawskim oraz w uniwersytetach w Poznaniu i Toruniu. Ponadto jego 
zagraniczne podróże naukowe w latach 1956-1987 do Niemiec, Czech, na Węgry i do Rosji przyczyniły się do poszerzenia możliwości stosowania metody porównawczej w twórczości naukowej, oraz spojrzenia na sztukę polską w kontekście europejskim. Szczególnie owocny był wyjazd do Rosji, gdzie w stolicy ówczesnego Związku Radzieckiego odnalazł wiele zabytków polskiego złotnictwa.

W 1992 roku nasz Jubilat przyjął nominację na tytuł profesora tzw. belwederskiego, z rąk ówczesnego prezydenta Lecha Wałęsy. Z kolei stanowisko profesora zwyczajnego na PAT uzyskał w pięć lat później. Doczekał się też uznania za pracę nad sztuką sakralną ze strony władz kościelnych, najpierw od Kardynała Prymasa Stefana Wyszyńskiego, a w latach 90-tych od Kardynała Metropolity Krakowskiego Franciszka Macharskiego.

W działalności naukowej i dydaktycznej na wyższych uczelniach i w instytucjach naukowych Profesor Jan Samek działa nadal jako członek w komisjach i stowarzyszeniach o charakterze naukowym: w Komisji Teorii i Sztuki PAN, Komisji Historii i Kultury Żydów Polskich PAU, w pięciu komisjach rektorskich UJ i PAT, w Stowarzyszeniu Historyków Sztuki, gdzie kierował Sekcją Rzemiosła Artystycznego, oraz w Towarzystwie Miłośników Historii i Zabytków Miasta Krakowa, a także w Radzie Naukowej Muzeum Historycznego Miasta Krakowa. Bierze nadal czynny udział w licznych seminariach, sesjach i kongresach.

$\mathrm{Za}$ zasługi na polu naukowym Profesor Jan Samek otrzymał wiele nagród, m. in. Prezesa Rady Ministrów, Prezydenta Miasta Krakowa, Nagrodę im. św. Brata Alberta, Instytutu Pedagogiki, wielokrotną nagrodę Rektora Uniwersytetu Jagiellońskiego, Towarzystwa Asystentów, Nagrodę im. Włodzimierza Pietrzaka, główną nagrodę Stowarzyszenia Historyków Sztuki, Złoty Krzyż Zasługi, oraz Złote Odznaki za pracę dla Miasta Krakowa i Ziemi Krakowskiej. Życiorys naukowy Profesora J. S. Samka oraz jego „Bibliografia” prac (licząca 434 publikacji i 261 pozycji przygotowanyçh do druku) dają obraz życia niesłychanie aktywnego i bogatego wewnętrznie. Świadczą o umiejętności łączenia przez Profesora posiadanej wiedzy i zamiłowania do historii sztuki, a w szczególności sztuki sakralnej i złotnictwa kościelnego z praktyczną i niemal wrodzoną zdolnością jej przekazywania innym.

Nie można pominąc faktu, iż w czasach PRL niejednokrotnie wywierano na Jubilata naciski, dając do zrozumienia, iż władzom nie podobały się jego zainteresowania głównie sztuką kościelną i klasztorną (od 1948). Ponadto tego rodzaju zainteresowania i kierunek twórczości powodowały do roku 1989 opóźnienia w powoływaniu go na stanowiska kierownicze oraz wydłużały proces związany $\mathrm{z}$ uzyskaniem docentury, a potem profesury.

Reasumując należy stwierdzić, iż pomimo tak wielu lat wytężonej pracy Jubilat nadal emanuje energią i siłą działania, podejmuje nowe inicjatywy i na bieżąco realizuje wcześniej wytyczone zadania. Kieruje się od lat przyjętą po swoich wielkich Profesorach historii sztuki i wychowawcach młodzieży dewizą: "Quidquid agis prudenter agas et respice finem". Tymi zadaniami na dzień dzisiejszy są idee wychowania przez sztukę kościelną i klasztorną. Osiagnięcie tak wielu sukcesów w życiu Profesora było możliwe między innymi dzięki ogromnej jego wytrwałości i cierpliwości. Podchodzi do wszelkich życiowych trudności 
z prawdziwie stoickim spokojem. Pewną odskocznię w wytężonej pracy stanowiły dla Jubilata zamiłowania kolekcjonerskie, które służyły zawsze i służą dziś w pracy dydaktycznej i zaspokajaja wewnętrzna potrzebę fascynacji pięknem niematerialnym, działającym na wrażliwą wyobraźnię. Naszego Jubilata cechuje głębokie życie wewnętrzne ujawniające się najbardziej w kręgu rodziny, w ciszy „domowego ogniska", gdzie powstawały i powstają m. in. prace o sztuce sakralnej i jej odniesieniach z kultem Istoty Najwyższej, z Bogiem ${ }^{43}$. Poznawaniu tej sztuki i dzieleniu się własnymi przeżyciami i przemyśleniami Profesor poświęcił ponad 50 lat swego twórczego życia.

Profesor Jan Sławomir Samek jest jednym z najwybitniejszych specjalistów w zakresie sztuki, a w tym także rzemiosła artystycznego, tak świeckiego jak i kościelnego w Polsce. Według znawców przedmiotu także sztuki środkowej i wschodniej Europy, o czym niech świadczą słowa wielkiego znawcy rzemiosła artystycznego Profesora Adama Bochnaka: ,JJan Samek/ ... poruszył w swoich pracach znaczną część zagadnień związanych z tematyką sztuki (...) po raz pierwszy w polskiej literaturze zajał się „konceptami”, spojrzał na sztukę (...) z nowego punktu, wykazując duża znajomość materiału zabytkowego, wiele dzieł zauważonych w czasie licznych podróży po kraju wprowadził do nauki po raz pierwszy, prawidłowo je interpretując, słowem posunął wiedzę naprzód"44.

${ }^{43} \mathrm{Z}$ relacji Żony Jubilata Izabelli Rejduch-Samkowej z 20.10.2000 r.

${ }^{44}$ Archiwum UJ Rkp. A. Bochnak, Opinie /o pracach dyplomowych/. 